\title{
Economic Burden Bore by Patients and Families because of stroke: Policy Assessment
}

\author{
* Honesty Fadhilah, ** Vetty Yulianty Permanasari \\ *,** Health Policy and Administration Department Faculty of Public Health Universitas Indonesia, F Building $1^{\text {st }}$ Floor \\ Kampus Baru UI Depok 16424, Indonesia
}

Email : honesty.fadhilah@gmail.com

\begin{abstract}
Stroke to this day is still a disease that causes a high disability. In the future, it will require a prohibitive cost so that it has an impact on the socio-economic consequences for patients and their families. The price is prohibitive so that the impact on socioeconomic implications for patients and their families. Because of that, the purpose of the study is to estimate the cause of the cost that causes an economic burden from a stroke. The method that is used is a content analysis by doing a further literature review from various sources, from journal to textbook from a national level to international. Literature studies show that direct medical cost, which is rehabilitation, and nursing care cost is identified as the leading contributor to the high price of economic burden from a stroke. High costs incurred cause family to experience catastrophic financial disaster; it even impacts to drop welfare level. Social preventive action is needed to reduce the high prevalence of stroke to reduce the cost, to protect every household from financial disaster from a stroke.
\end{abstract}

Keywords: stroke, economic burden, cost

\section{INTRODUCTION}

Stroke clinical signs develop rapidly from focal (or global) disturbance of the cerebral function with symptoms that lasted for 24 hours or more even can lead to death, without apparent cause apart from a vascular origin ${ }^{(1)}$. Stroke causes sudden death of several brain cells due to the lack of oxygen. When the bloodstream going to the brain is gone or reduced by the presence of clogging or rupture in the blood vessel from the artery to the brain ${ }^{(1)}$. A Stroke happens because the blood flow to the brain is disturbed so that without oxygen-rich blood, brain cells will die. Stroke is the leading cause of long-term disability and preventable disability. Stroke or vascular dementia is the leading cause of memory loss ${ }^{(2)}$.

The risk factor of stroke is similar to coronary heart disease and other vascular diseases, which are unhealthy lifestyles like smoking, low physical level of exercise, unhealthy diet, and obesity ${ }^{(2,3)}$. Other diseases that can become a risk factor are hypertension, hyperlipidemia, and diabetes ${ }^{(3)}$.

Cerebrovascular disease(stroke) is the second leading cause of death and the third leading cause of disability in the world ${ }^{(3)}$. In the united states of America, every 4 minutes someone dies because of stroke ${ }^{(2)}$. In Qatar, cardiovascular disease cause $15 \%$ of all death ${ }^{(4)}$. In subSaharan Africa, where it is going through an epidemiology transition, stroke, and other vascular diseases contribute even more to the morbidity of the disease $^{(6)}$. Stroke is also the leading cause of dementia and depression ${ }^{(3)}$.

In Indonesia, stroke is the leading cause of death for people age above five years old, which is around 15,4\% of all death ${ }^{(7)}$. Based on the data from Riset Kesehatan Dasar (Riskesdas) in the year 2018, the prevalence of stroke is 10,9 for every 1.000 citizens. This number is increasing compared to the result of Riskesdas 2013, which is 7 for every 1.000 citizens. Stroke has become the leading cause of death in almost all hospitals in Indonesia, which is around $15,4 \%{ }^{(8,9)}$.

Stroke has significant mortality, morbidity, and socialeconomic consequence for the patients, their partner, and society ${ }^{(10)}$. In South Africa, stroke is a disease with a high economic burden ${ }^{(7)}$. Stroke is a significant economic burden for the resident of turkey ${ }^{(11)}$. As an illustration, the highest overall cost (outpatient/inpatient care) reported in the USA (average cost $4.644 \$$ for a patient every one month), followed by Denmark, Hollan, and Norway. The service utilization component in which rehabilitation and care are identified as a significant contributor to the total cost of rehabilitation services ${ }^{(12)}$. 
In addition to being a burden on the country, a series of treatments, therapy, and rehabilitation therapies undertaken by stroke patients also pose a significant economic burden to the patient and the patient's family. Stroke is a big challenge for patients and their families, the number of direct costs that must be incurred for acute care and rehabilitation and indirect costs due to lost productivity of patients and their families is also a significant burden for the health care system ${ }^{(13)}$. Despite improvements in the prevention of primary and secondary cardiovascular disease, acute ischemic stroke remained a significant burden on the high-volume health care system at visits and increased care costs ${ }^{(14)}$. For this reason, researchers try to conduct a literature study to determine the economic burden borne by patients and families caused by stroke.

\section{METHOD}

This journal IS using literature study techniques/literature review to obtain information related to stroke health problems including the magnitude of the problem of stroke and the economic burden bore by patients and families caused by stroke. Information was taken from various data sources, including the results of the 2013 and 2018 Survey Kesehatan Dasar (Riskesdas), the results of studies conducted by the Ministry of Health, previous studies on the topic of stroke especially the burden of stroke and the economic burden of stroke, and the rules and policies related to social security.

\section{RESULT AND DISCUSSION}

\section{The Magnitude of the Stroke Problem}

Worldwide, stroke is the second leading cause of death and the third leading cause of disability (DALY) ${ }^{(15)}$. Also, the global burden of stroke increased between 1990 and 2010, the number of stroke-related deaths increased by $26 \%$, and DALY or record due to stroke also increased by $19 \%{ }^{(15)}$. Globally, $90.5 \%$ of the stroke burden (measured in DALY) is caused by modifiable risk factors such as unhealthy living behaviors $^{(16)}$.

Until four decades ago, the incidence of stroke in low and middle-income countries was much lower than in economically stronger countries ${ }^{(17)}$. However, in the following years, the incidence of strokes in places like southern India and rural South Africa was about two times higher compared to before, while the rate of strokes in economically more developed countries decreased ${ }^{(17)}$. The level of disability and death from stroke is ten times greater in countries that are medically under-served compared to developed countries ${ }^{(17)}$.

Stroke is a global epidemic, and the problem of stroke is by no means limited to western or high-income countries ${ }^{(18)}$. About $85 \%$ of all deaths from stroke are recorded in low and middle-income countries, which also accounts for $87 \%$ of total losses due to stroke (DALY) accounting for 72 million per year worldwide (18). Stroke burden is disproportionately higher in China, Africa, and South America, while the burden of IHD (Ischemic Heart Disease) is higher in the Middle East, North America, Australia and most of Europe. Lower national income is associated with relatively higher mortality and disease burden due to stroke ${ }^{(19)}$.

The global burden of stroke is high, including increased incidence, mortality, DALY, and economic impacts, especially in low and middle-income countries ${ }^{(20)}$. Population growth and aging play an essential role in the increase of observed stroke loads ${ }^{(16)}$.

A better implementation of surveillance systems and prevention programs is needed to help track current trends and to inhibit the projected exponential increase in stroke worldwide ${ }^{(20)}$. A Global mapping is an important method and tool for visualizing stroke loads and trends in various regions and countries ${ }^{(16)}$

In Indonesia, based on data from Riset Kesehatan Dasar (Riskesdas) in 2018, the prevalence of stroke is 10.9 per 1,000 population. This is an increase when compared to the results of Riskesdas 2013, which amounted to 7.0 per 1000 population ${ }^{(8.9)}$.

\section{The Economic Burden of Stroke}

Although this study is not using a complete economic evaluation technique, it can be used to provide information and identify the costs incurred by disease using the study of the cost of illness. The costs calculated in the cost of illness are:

a) Direct Cost, which is the costs that exist in the health care system, community, patients, and families directly related to the illness.

b) Indirect Cost, i.e. loss of productivity due to illness, costs incurred by the patient, the community, or the patient's family or employer.

Intangible Cost, which is costs that cannot or are difficult to calculate or quantify, which usually consists of pain, sadness/sorrow, and suffering and loss of leisure time due to illness. 


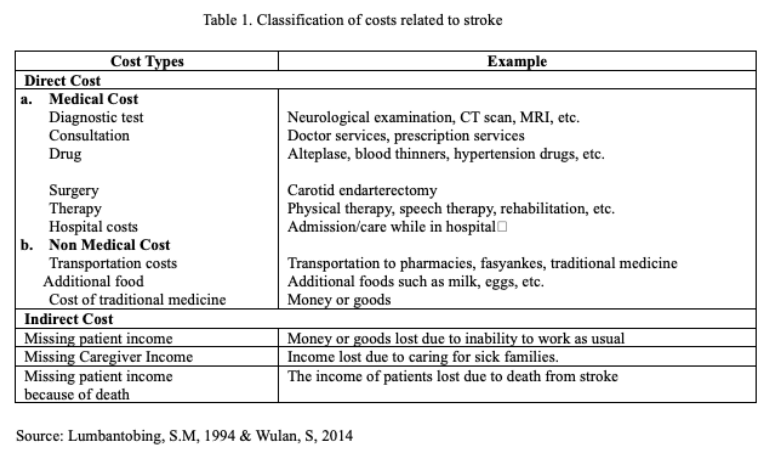

The literature review revealed that the majority of costrelated analyzes focused on short-term care in hospital and acute care as the main drivers of stroke inpatient costs ${ }^{(13,21,22)}$. Also, long-term medical costs resulting from rehabilitation and outpatient care as well as indirect expenses from lost income and informal expenses are the most significant burden on lifetime stroke costs ${ }^{(12)}$. Further research focusing on long-term and indirect expenditure is critical to assess the impact of new treatments on the total cost of stroke. Overall, the high costs associated with stroke indicate there is a vital need for effective preventive therapy, acute care, and rehabilitation, which in turn will reduce national spending on health services related to stroke and increase productivity ${ }^{(21)}$.

\section{Coping strategy}

In response to a sick family member, another household member will decide to seek treatment ${ }^{(23) \text {. If }}$ the disease is severe, household members will sacrifice their work time to maintain the family and seek expenses for the treatment of sick families (23). Coping strategy is an action that aims to regulate the cost of an event or process (for example, sick), which will threaten the welfare of one or more household members. In the end, the coping strategy seeks to maintain economic viability and household sustainability (23).

Several studies have identified household coping strategies in dealing with a disease, such as taking a loan, selling assets, and even preventing costs that would arise by ignoring the disease / not doing a treatment. Two critical factors for household success in overcoming the costs of falling ill are the ability of households to overcome shocks (shock) with wealth (assets) owned in the form of physical capital, finance, education, and community resources. Secondly, the ability to cope is greatly influenced by the type, severity, and duration of the disease itself, and this is related to the use of different resources for each disease trait (23).

The loss of workdays and the decline in household welfare due to stroke makes the patient or family coping strategy by taking a loan from the bank, selling assets, or doing both. Coping Strategy is an action that aims to regulate costs such as illness, which will threaten the welfare of one or more household members (23). The burden of disease due to stroke plus households conducting coping strategies will worsen the economic situation of households that have low incomes (23).

\section{Catastrophic}

Catastrophic financial disasters are direct payments from personal pockets (Out of Pocket) that exceed 10\% of total household income (23). Expenditures from personal pockets (out of pocket) for health are any direct expenditure by households including gratuities in the form of payment for consulting services, medicines, therapeutic equipment, and other goods/services that contribute to improving health status. This definition can include transportation costs for accessing health services and medicines at pharmacies, and consumables, but does not include taxes related to health or insurance (16).

Studies on the analysis of stroke costs show out of pocket costs incurred due to stroke is $\$ 103,576$ on average in all stroke subtypes, with acute care costs incurred within 2 years after the first stroke accounted for $45.0 \%$, long-term outpatient care length accounted for $35.0 \%$, and rehabilitation costs accounted for $17.5 \%$ of the total lifetime cost of a stroke (24). Meanwhile, in Indonesia, the total cost of a stroke that must be incurred by patients is Rp. 643,783,379.40. The average cost in the first episode of a stroke inpatient is Rp. 13,826,124,54 \pm Rp. 8,627,671.85 and the first episode of outpatient Rp. 600,215.97, - \pm Rp. $365,042,33$. (13)

The choice of stroke calculation from the perspective of the patient is used because the economic burden bore by stroke patients and household members are quite high, not only the direct costs associated with the health care system but also the impact of health care interventions in the broader family economy, specifically, in reducing costs for work absenteeism due to illness (25). Even households often fall into poverty because they finance health services (26).

People who suffer a stroke cannot work, which affects productivity. Other household members are affected, not only to help support the family's economy but also to pay medical expenses for patients and for health services whose value is very significant. Caring for stroke patients puts social, emotional, health, and financial pressure on informal caregivers (family members). These burdens and tensions increase with the duration of a stroke, intimacy, the small number of caregivers, and the length of caregiving every day (22). 
The economic burden will be more severe if households do not have health insurance and make cash payments for stroke treatment. With limited resources, households would sell assets or take debt for the cost of stroke treatment, causing households to experience catastrophic and decrease the level of welfare.

\section{CONCLUSION}

Literature studies show that direct medical costs in the form of rehabilitation costs and nursing care are identified as the main contributors that cause the high economic burden bore by patients and families due to stroke. The high out of pocket costs incurred caused families experiencing catastrophic financial disasters. Meanwhile, coping strategies carried out by patients' families due to the high economic burden due to stroke caused patients and families to experience long-term financial threats that result in a decrease in family welfare.

\section{SUGGESTION}

Social preventive measures are needed to reduce the magnitude of the prevalence of stroke in order to reduce the burden of costs, in order to protect every household from the financial threat due to stroke. This result is also useful for determining policies in the health sector, for health planning and budgeting. An example is the number of costs incurred/needed by the government annually incurred in the benefits of health insurance for the treatment of patients suffering from a stroke.

\section{ACKNOWLEDGEMENT}

The author would like to thank the reviewers and editors of the Journal of IHPA for their comments. Special thanks to Ms. Vetty Yulianty Permanasari as a mentor who has provided support to many authors to publish this article.

\section{REFERENCE}

1. WHO. The Global Burden Of Cerebrovascular Disease. 2000; Available from:

http://www.who.int/healthinfo/statistics/bod_ce rebrovasculardiseasestroke.pdf

2. American Heart Association. Stroke Fact Sheet. 2016; Available from: www.strokeassociation.org/idc/groups/strokepublic/@wcm/@hcm/@sta/documents/downloa dable/ucm_485076.docx

3. WHO. Stroke : A Global Response Is Needed. 2016; Available from:

http:/www.who.int/bulletin/volumes/94/9/16181636/en/

4. Faisal Ibrahim, Deleu D, Akhtar N, Wafa AlYazeedi BM, Sadaat Kamran and AS. Burden of Stroke in Qatar. Journal of Stroke and Cerebrovascular Diseases. 2015;24(12):28759. Available from:

http://dx.doi.org/10.1016/j.jstrokecerebrovasdi s.2015.08.024

5. Y.Y. Lee, A.A. Shafie, N.N. Sidek ZAA. Economic burden of stroke in malaysia: results from national neurology registry. J Neurol Sci 381. 2017;

6. Connor MD, Walker R, Modi G, Warlow CP. Burden of stroke in black populations in subSaharan Africa. Lancet Neurol [Internet]. 2007;6(3):269-78. Available from: https://doi.org/10.1016/S1474-4422(07)700029

7. Kusuma Y, Venketasubramanian N, Kiemas LS, Misbach J. Burden of stroke in Indonesia. Int J Stroke 2009 [Internet]. 2009;4(5):379-80. Available from: https://doi.org/10.1111/j.17474949.2009.00326 .x

8. Kemenkes RI. Riset Kesehatan Dasar 2013. Jakarta: Balitbangkes; 2013.

9. Kemenkes RI. Riset Kesehatan Dasar 2018. Jakarta: Balitbangkes; 2018.

10. Jennum P, Iversen HK, Ibsen R, Kjellberg J. Cost of stroke: a controlled national study evaluating societal effects on patients and their partners. BMC Health Serv Res. 2015;

11. İçağasıoğlu A, Baklacıoğlu HŞ, Mesci E, Yumuşakhuylu Y, Murat S, Mesci N. Economic burden of stroke. Turk J Phys Med Rehab 2017. 2017;63(2):155-9.

12. Rajsic S, Gothe H, Borba HH, Sroczynski G, Vujicic J, Toell T, et al. Economic Burden of Stroke: A Systematic Review on Post-Stroke Care. Value Heal. 2016;33(11).

13. Setyawan IA, Andayani TM, Pinzon RT. Analisis Biaya Penyakit Stroke Perdarahan Di Rumah Sakit. J Manaj dan Pelayanan Farm 2016. 2016;6(1).

14. Stuntz M, Busko K, Irshad S, Paige T, Razhkova V, Coan T. Nationwide trends of clinical characteristics and economic burden of emergency department visits due to acute ischemic stroke. Emerg Med [Internet]. 2017;9:89-96. Available from: http://dx.doi.org/10.2147/OAEM.S146654

15. Hankey GJ. The global and regional burden of stroke. 2013;8(4). Available from: http://dx.doi.org/10.1016/ S2214- 
109X(13)70095-0

16. Feigin VL, Roth GA, Naghavi M, Parmar P, Krishnamurthi R, Chugh S, et al. Global burden of stroke and risk factors in 188 countries, during 1990-2013: a systematic analysis for the Global Burden of Disease Study 2013. Lancet Neurol [Internet]. 2016;15(9):913-24. Available from: http://dx.doi.org/10.1016/ S14744422(16)30073-4

17. Norrving B, Kissela B. The global burden of stroke and need for a continuum of care. Neurol J [Internet]. 2013;15(1). Available from: https://doi.org/10.1212/WNL.0b013e31827623 97

18. Carlo A Di. Human and economic burden of stroke. Age Ageing 2009 [Internet]. 2009;38(1):4-5. Available from: https://doi.org/10.1093/ageing/afn282

19. Kim AS, Johnston SC. Global Variation in the Relative Burden of Stroke and Ischemic Heart Disease. 2011; Available from:

https://doi.org/10.1161/CIRCULATIONAHA. 111.018820

20. Mukherjee D, Patil CG. Epidemiology and the Global Burden of Stroke. World Neurosurg [Internet]. 2011;76(6):85-90. Available from: https://doi.org/10.1016/j.wneu.2011.07.023

21. Demaerschalk BM, Hwang H-M, Leung G. US Cost Burden of Ischemic Stroke: A Systematic Literature Review. Am J Manag Care [Internet]. 2011; Available from: https://www.ajmc.com/journals/issue/2010/201 0-07-vol16n07/ajmc_10demaerschalkburdn_525? $\mathrm{p}=1$

22. Gbiri CA, Olawale OA, Isaac SO. Stroke management: Informal caregivers' burdens and strians of caring for stroke survivors. Ann Phys Rehabil Med [Internet]. 2015;98-103.

Available from:

http://dx.doi.org/10.1016/j.rehab.2014.09.017

23. Wulan S. Beban Ekonomi Yang Ditanggung Pasien Dan Anggota Rumah Tangga Akibat Penyakit Tuberculosis Di Kota Bengkulu Tahun 2013. Universitas Indonesia; 2014.

24. Taylor TN, Davis PH, Torner JC, Holmes J, Meyer JW, Jacobson MF. Lifetime Cost of Stroke in the United States. 1996;1459-66. Available from:

https://doi.org/10.1161/01.STR.27.9.1459
25. Pritchard C, Sculpher M. Productivity Cost: Priciples and Practice in Economic Evaluation. . London: Office of Health Economic. 2000;

26. Nadjib M, Pujiyanto. Pola Pengeluaran Rumah Tangga Untuk Kesehatan Pada Kelompok Marginal dan Rentan Miskin. 2002;6(12). 